\title{
MULTICULTURALISM: SECTION 27'S APPLICATION IN CHARTER CASES THUS FAR
}

\author{
DINO BOTTOS*
}

\section{INTRODUCTION}

The Canadian Charter of Rights and Freedoms ${ }^{1}$ contains a provision that is a manifestation of an uniquely Canadian policy - multiculturalism. Section 27 of the Charter reads:

This Charter shall be interpreted in a manner consistent with the preservation and enhancement of the multicultural heritage of Canadians.

The fact that the section is an interpretive provision extending to the whole Charter should make it clear that it is to be considered in every applicable case. This notion, however, has thus far existed in theory rather than in practice.

Within the scope of this paper, it is the author's objective to firstly, present a possible meaning and application of section 27; secondly, review the application of the section in the case law thus far; thirdly, briefly discuss some of the problems that have arisen from these cases; and finally, postulate a possible solution to the section's use.

\section{A DEFINITION}

As the word culture is the root-word of multicultural and multicultural or multiculturalism is the focus of s. 27, it is important to understand what comprises a culture. In the case of R. v. W.H. Smith Ltd. ${ }^{\text {IA }}$ His Honour Judge Jones, in considering s. 27, used Webster's Third New World Dictionary ${ }^{2}$ to define culture as: ${ }^{3}$

Sa: the total pattern of human behavior and its products embodied in thought, speech, action, and artifacts and dependent upon man's capacity for learning and transmitting knowledge to succeeding generations through the use of tools, language, and systems of abstract thought b: the body of customary beliefs, social forms, and material traits constituting a distinct complex tradition of racial, religious, or social group . . . that complex whole that includes knowledge, belief, morals, law customs, opinions, religion, superstition, and art. ...

This definition alerts us to similar concepts manifested in the Charter. An overview of the Charter reveals that the most applicable sections to a s. 27 interpretation are ss. 2 (fundamental freedoms), 14 (right to an interpreter), 15 (equality rights), $16-22$ (rights in relation to the official

- Dino Bottos is a law student at the University of Alberta. This note is the winning entry in the 1988 William Morrow Essay Competition, case comment portion.

1. Canadian Charter of Rights and Freedoms, as enacted in Canada Act 1982 (U.K.), c. 11.

1A. (1983) 26 Alta. L.R. 238 (Alta. Prov. Ct.).

2. (1964) G. and C. Merrian Company.

3. Id. at 261. 
languages), 23 (minority language educational rights), 25 (Aboriginal rights), 26 (rights existing before the Charter), and 29 (rights respecting the preservation of privileges of certain schools). It is submitted that as a consequence of the above sections containing elements of culture, their application in relevant Charter matters should be accompanied by a s. 27 interpretation.

\section{CASE LAW}

Section 27 has thus far been used in three general areas of the Charter case law: s. 2(a), freedom of conscience and religion; s. 23, minority language educational rights; and the criminal law. As well, s. 15(1) has been discussed in conjunction with various cases within these three areas. ${ }^{4}$

\section{A. FREEDOM OF CONSCIENCE AND RELIGION}

In the case of $R$. v. W.H. Smith Ltd. ${ }^{\text {s }}$ various retail stores were charged for selling goods on a Sunday contrary to the federal Lord's Day Act. ${ }^{6}$ His Honour Judge Jones defined the term "culture" and concluded that since religion was an element of culture, s. 27 was applicable. By considering s. 27, His Honour appreciated the fact that some religions, such as the Moslem, Jewish, and Seventh Day Adventist faiths do not wish to be bound by Sunday observance as their Sabbaths fall on other days of the week. He then went on to hold that the statute "... tries to coerce them [adherents of non-Sunday observing religions] into following Sunday observance" ${ }^{8}$ His Honour then added: 9

The support given to one element of the population of Canada by the Lord's Day Act (Canada) ... is an unacceptable preference by the state for the religious beliefs of some Christians.

His Honour, however, was careful to point out that because of special provisions under s. 93 of the Constitution Act 1867 and maintained in s. $29^{10}$ of the Charter with respect to denominational, separate and dissentient schools, and the fact that historically Canada has had a Christian background,"

... lead me to admit that my remark above about a "measure of equal treatment" being called for by s. 27 of the Charter means no more than the phrase suggests, because for the reasons noted and others, it may be that full equality is neither possible nor desirable. The word "multicultural" of course recognizes the importance of the diverse cultural backgrounds involved.

4. However, Section 15 was not proclaimed until April 17, 1985.

5. Supra, n. 1a.

6. R.S.C. 1970 , c. L-13.

7. Supra, n. 3.

8. Supra, n. 1 at 268.

9. Id.

10. Section 29 of the Charter reads:

Nothing in this Charter abrogates or derogates from any rights or privileges guaranteed by or under the Constitution of Canada in respect of denominational, separate or dissentient schools.

11. Supra, n. 1 at 261. 
The next case that dealt with the federal Lord's Day Act, was R. v. Big $M$ Drug Mart Ltd. ${ }^{12}$ In the Supreme Court of Canada the Act was held unconstitutional as it infringed the accused's freedom of conscience and religion. Mr. Justice Dickson (as he then was), speaking for a unanimous court, described the purpose of the Charter in relation to the protection of minorities from majoritarian coercion: $:^{13}$

One of the major purposes of the Charter is to protect within reason from compulsion or restraint. Coercion includes not only such blatant forms of compulsion as direct commands to act or refrain from acting on pain of sanction, coercion includes indirect forms of control which determine or limit alternative courses of conduct available to others.

He later added:14

What may appear good and true to a majoritarian religious group, or to the state acting at their behest, may not, for religious reasons, be imposed upon citizens who take a contrary view. The Charter safeguards religious miniroties from the threat of "the tyranny of the majority".

Mr. Justice Dickson strengthened the argument for minorities' freedom of religion by referring to $s .27::^{15}$

I agree ... that to accept that Parliament retains the right to compel universal observance of the day of rest preferred by one religion is not consistent with the preservation and enhancement of the multicultural heritage of Canadians. To do so is contrary to the expressed provisions of s. 27.

In the Ontario Court of Appeal's decision of $R$. v. Videoflicks, ${ }^{16}$ and the Supreme Court of Canada case which subsequently overruled it, Edwards Books and Art Ltd. v. The Queen, ${ }^{17}$ various retail store owners were charged with Sunday opening offences under the Ontario Retail Business Holidays Act. ${ }^{18}$ The Act was not as strict as the federal Lord's Day Act, in that the former provided for exemptions to stores which were closed (essentially) on Saturdays, and used no more than seven workers and up to 5,000 square feet of retail space when open on Sundays.

Mr. Justice Tarnopolsky, speaking for a unanimous Court of Appeal, formulated a definition of freedom of religion stressing in it not only the freedom to believe and practice the faith, but also to manifest it. ${ }^{19} \mathrm{His}$

12. [1985] 1 S.C.R. 295, 18 D.L.R. (4th) 321, 18 C.C.C. (3d) 385, [1985] 3 W.W.R. 481, 37 Alta. L.R. (2d) 97, 60 A.R. 161,85 C.L.L.C. para 14,023, 13 C.R.R. 64, 58 N.R. 81.

13. Id. W.W.R. at 518 .

14. Id.

15. Id. at 519.

16. (1984) 14 D.L.R. (4th) 10, 48 O.R. (2d) 295, 34 R.P.R. 97, 15 C.C.C. (3d) 353, 9 C.R.R. 193, SO.A.C. 1 (C.A.).

17. (1987) 35 D.L.R. (4th) 1.

18. R.S.O. 1980, c. 453.

19. This was derived from Article 18 of the International Covenant on Civil and Political Rights, ratified in Canada in 1976. Article 18(1) states:

(1) Everyone shall have the right to freedom of thought, conscience and religion. This right shall include freedom to have or to adopt a religion or belief of his choice, and freedom, either individually or in community with others and in public or private, to manifest his religion or belief in worship, observance, practice and teaching. 


\section{l_ordship achieved this on the strength of s. 27's application: ${ }^{20}$}

It is thus the clear purpose of s. 27 that, where applicable, any right or freedom in the Charter shall be interpreted in light of this section. Religion is one of the dominant aspects of a culture which it is intended to preserve and enhance. In this regard, art. 27 of the Covenant on Civil and Political Rights provides:

\section{ARTICLE 27}

In those States in which ethnic, religious or linguistic minorities exist, persons belonging to such minorities shall not be denied the right, in community with the other members of their group, to enjoy their own culture, to profess and practice their own religion, or to use their own language.

Therefore, my conclusion that a law infringes freedom of religion, if it makes it more difficult and more costly to practise one's religion, is supported by the fact that such a law does not help to preserve and certainly does not serve to enhance or promote that part of one's culture which is religiously based. Section 27 determines that ours will be an open and pluralistic society which must accommodate the small inconveniences that might occur where different religious practices are recognized as permissible exceptions to otherwise justifiable homogeneous requirements.

As the exemptions provision "did not go far enough", ${ }^{21}$ the Act was held :o be an infringement on freedom of religion; and, since it was further determined that there was insufficient evidence that the Act was a :easonable limit as required by s. 1 of the Charter, the Court held the Act of no force or effect. ${ }^{22}$

In the Supreme Court, five of seven judges agreed that the Act infringed 3. 2(a) of the Charter, but of those five, only Madam Justice Wilson held that it could not be saved by section 1 of the Charter. For the majority, Chief Justice Dickson concluded, from the evidence,,$^{23}$ that a common day of rest was essential to the preservation of family life, and valued by members of society in general. This sufficed to have the Act pass the analysis in $R$. v. Oakes ${ }^{24}$ on the application of $s .1$ of the Charter.

It is submitted that this conclusion is fair in most cases; however, it should be considered that a "common day of rest" for many people is the day on which they observe their Sabbath. Thus, retail owners of religious faiths that respect Sabbath days other than Sunday could be impelled to close two days a week rather than one (unless their businesses operate within the limitations stipulated for the Sunday openings). As well, Madam Justice Wilson pointed out that the Ontario Human Rights Code provides a remedy for those employees who have unreasonably been denied their request for having a day off on their Sabbath. The appeal to the Human Rights Board would have been a less obtrusive method of ensuring a common rest day for Sunday observers.

20. Supra, n. 16 C.C.C. at $385-386$.

21. Id. at 386.

22. Section 1 of the Charter reads:

The Canadian Charter of Rights and Freedoms guarantees the rights and freedoms set out in it subject only to such reasonable limits prescribed by law as can be demonstrably justified in a free and democratic society.

23. The Report on Sunday Observance Legislation (1970).

24. [1986] 1 S.C.R. 103, 50 C.R. (3d) 1, 24 C.C.C. (3d) 321, 14 O.A.C. 335, 65 N.R. 87. 
Only Madame Justice Wilson was willing to apply s. 27 to strengthen the religious rights of all non-Christians. In her discussion of group rights she concludes:2s

\begin{abstract}
It seems to me that s. 3(4) of the Retail Business Holidays Act purports to recognize a group right, namely the right of those who close on Saturdays on religious grounds to stay open on Sundays because otherwise their s. 2(a) right would be violated. But it does not recognize the group right of all members of the group, only of some. Accordingly, the violation of the s. 2(a) right of the others has legislative sanction. Yet it seems to me that when the Charter protects group rights such as freedom of religion, it protects the rights of all members of the group. It does not make fish of some and fowl of the others. For, quite apart from considerations of equality, to do so is to introduce an invidious distinction into the group and sever the religious and cultural tie that binds them together. It is, in my opinion, an interpretation of the Charter expressly precluded by s. 27 which requires the Charter to be interpreted "in a manner consistent with the preservation and enhancement of the multicultural heritage of Canadians". Can it then be a reasonable limit under s. 1 ? In my opinion, it can not.
\end{abstract}

In the case of Hothi v. $R_{.}{ }^{26}$ the applicant defendant claimed that his rights under ss. 2(a) and 27 of the Charter were abrogated by a Provincial Judge because the applicant was not allowed to wear his kirpan (a six-inch dagger worn by males of the Sikh faith) into the courtroom. In dismissing the application, the Court of Appeal relied on s. 1 of the Charter and Article 18 of the International Covenant on Civil and Political Rights ${ }^{27}$ to justify limiting the applicant's freedom of religion. The concern for courtroom safety, coupled with the fact that the applicant was being tried for assault charges, justified the limitation. Section 27 was not specifically mentioned in the judgment.

The case of Re Zylberberg and the Director of Education ${ }^{28}$ presents an odd and, with respect, dissatisfactory use of $s$. 27. The majority of the Ontario Court of Appeal upheld a provision of the Ontario Education Act that ordered the "reading of Scripture or other suitable readings and repeating of the Lord's Prayer or other suitable prayers" in public schools. Disregarding the possibility of children of minority faiths feeling compelled to participate in the activities, ${ }^{29}$ the majority explained that 5.27 should be used to instill pride in the identity of minority groups; the children should use the opportunity of opting out to manifest their cultural differences.

This view ignores the fact that children are particularly sensitive to peer pressure and may, due to emotional pain and embarrassment, deny their differences from the majority. It is unfair to thrust upon a child the responsibility of holding oneself out as "different" when that child may not be emotionally prepared to do so. Arguably, such experiences would more often than not adversely affect the child's psychological or emotional makeup, thereby fostering internal alienation. In this case s. 27 was used as requiring minority groups to act to preserve their culture rather than

25. Supra, n. 17 at $60-61$.

26. [1985] 3 W.W.R. 256, 14 C.R.R. 85, 33 Man. R. (2d) 180 (Q.B.); affirmed [1986] 3 W.W.R. 671, 35 Man. R (2d) 159 (C.A.).

27. Supra, n. 19.

28. Re Zylberberg and Director of Education of Sudbury Board of Education League for Human Rights of B'Nai Brith Canada, Intervenors (1986) 55 O.R. (2d) 749 (Ont. H.C.J.).

29. Parents had a right to opt-out of the religious activities on behalf of their children. 
allowing a remedy to them in court when their freedom of religion had been infringed..$^{30}$ It is submitted than s. 27 was not intended to operate in such a manner; the rights and freedoms contained in the Charter are available to those who choose to exercise them and cannot be foisted upon any person in a manner so as to dictate behaviour.

In Reference Re an Act to Amend the Education Act, ${ }^{31}$ the majority of the Ontario Court of Appeal upheld a bill that was to provide full funding for Roman Catholic high schools in the province. The issue was whether state funding of such schools could be squared with ss. 2(a), 15(1) and 27 of the Charter.

Chief Justice Howland and Justice Robins, concurring in dissent, held the view that: ${ }^{32}$

The Charter has established a new relationship between the individual and the State. Its text marks the metes and bounds of governmental authority and individual autonomy. It has been made part of the Constitution of Canada and, as such, forms part of the supreme law of Canada. By virtue of s. 52(1) of the Constitution Act, 1982, any law inconsistent with the Charter's provision is, to the extent of the inconsistency, of no force or effect.

In their dissent, s. 27 was used to give greater effect to ss. 2(a) and 15(1). Their Lordships claimed that propogation of special rights and privileges to certain groups is no longer justified since the Charter's proclamation and, therefore, s. 29 of the Charter could not operate to protect the further creation of privileges for denominational, separate or dissentient schools.

The majority, on the other hand, did not acknowledge the application of s. 27 at all. In effect, they held that the promise made to these schools in s. $93^{33}$ of the Constitution Act, 1867 at the time of Confederation, coupled

30. Mr. Justice Reid, in dissent, answers the assertions in a passage from Justice Dickson (as he then was) in R. v. Big M Drug Mart:

What may appear good and true to a majoritarian religious group, or to the state acting at its behest, may not, for religious reasons, be imposed upon citizens who take the contrary religious view. The Charter safeguards religious minorities from the threat of "the tyranny of the majority." (Supra, n. 12 at 518).

31. (1986) 25 D.L.R. (4th) 1, 53 O.R. (2d) 513, 13 O.A.C. 241.

32. Id. at 41 .

33. Subsections 93(1) and (2) of the Constitution Act, 1867 read:

93. In and for each Province the Legislature may exclusively make Laws in relation to Education, subject and according to the following Provisions:-

(1) Nothing in any such Law shall prejudicially affect any Right or Privilege with respect to Denominational Schools which any Class of Persons have by Law in the Province at the Union:

(2) All the Powers, Privileges, and Duties at the Union by Law conferred and imposed in Upper Canada on the Separate Schools and School Trustees of the Queen's Roman Catholic Subjects shall be and the same are hereby extended to the Dissentient Schools of the Queen's Protestant and Roman Catholic Subjects in Quebec: 
with the protection of these rights and privileges by s. 29 of the Charter, tipped the scales in favour of enshrined privilege, over that of equality. ${ }^{34}$

On appeal to the Supreme Court of Canada, ${ }^{35}$ a unanimous seven member Court held that the Charter would have no effect on repealing those privileges conferred upon certain minorities in the Constitution Act, 1867. Madam Justice Wilson stated: ${ }^{36}$

I have indicated that the rights or privileges protected by s. 93(1) are immune from Charter review under s. 29 of the Charter. I think this is clear. What is less clear is whether s. 29 of the Charter was required in order to achieve that result. In my view, it was not. I believe it was put there simply to emphasize that the special treatment guaranteed by the constitution to denominational, separate or dissentient schools, even if it sits uncomfortably with the concept of equality embodied in the Charter because not available to other schools, is nevertheless not impaired by the Charter. It was never intended, in my opinion, that the Charter could be used to invalidate other provisions of the constitution, particularly a provision such as $\mathbf{s .} 93$ which represented a fundamental part of the Confederation comprimise.

As with the majority of the Ontario Court of Appeal, the Supreme Court did not address the matter of interpreting s. 27, for the greater need of resolving the apparent inconsistencies between the Charter in toto and the Constitution Act, 1982 itself, took precedence.

\section{B. MINORITY LANGUAGE EDUCATION RIGHTS}

In Reference Re Education Act of Ontario and Minority Language Rights ${ }^{37}$ the Ontario Court of Appeal considered the constitutional validity of certain provisions of the Education Act, ${ }^{38}$ which dictated the criteria by which Francophone parents may have their children educated in

34. This is best shown on pages 54-55 D.L.R. where the majority states:

The Constitution of Canada, of which the Charter is now a part, has from the beginning provided for group collective rights in ss. 93 and 133 of the Constitution Act, 1867. As Professor Hogg (Peter W. Hogg, Constitutional Law of Canada, 2nd ed. (1985), at p. 634 and p. 824) has expressed it: these provisions amount to "a small bill of rights". The provisions of this "small bill of rights", now expanded as to the language rights of s. 133 by ss. 16 to 23 of the Charter, constitute a major difference from a bill of rights such as that of the United States, which is based on individual rights. Collective or group rights, such as those concerning language and those concerning certain denominations to separate schools, are asserted by individuals or groups of individuals because of their membership in the protected group. Individual rights are asserted equally by everyone despite membership in certain ascertainable groups. Collective rights protect certain groups and not others. To that extent, they are an exception from the equality right provided equally to everyone. Thus a court cannot rely on s. 15 to invalidate a provision for the English or French languages, pursuant to ss. 16 to 23 of the Charter, on the ground that such provision does not provide for equal protection or benefit to another language.

35. Reference Re An Act to Amend the Education Act (Ontario) (1988) 40 D.L.R. (4th) 18 (S.C.C.).

36. Id. at 60 .

37. (1984) 10 D.L.R. (4th) 491,47 O.R. (2d) 1, 27 M.P.L.R. 1, 11 C.R.R. 17 (Ont. C.A.).

38. R.S.O. 1980, c. 129. 
French language schooling facilities. As language is a constituent element of culture, the Court held that through the combination of ss. 27 and $23^{39}$ of the Charter, the Francophone minority had not only the right to a French language education, but that it was to be provided in publicly funded Francophone schooling facilities. Justice Tarnopolsky concluded:40

In the light of s. 27 , s. $23(3)(b)$ should be interpreted to mean that minority language children must receive their instruction in facilities in which the educational environment will be that of the linguistic minority. Only then can the facilities reasonably be said to reflect the minority culture and appertain to the minority.

It is evident from this example that s. 27 was a significant factor in establishing the rights of the Francophone community with regards to s. 23. The criteria proposed were, therefore, held to be inconsistent with the Charter.

The Ontario Reference was followed in Mahe v. Alberta. ${ }^{41}$ The plaintiffs, Francophone parents in Alberta, claimed that their rights under ss. 15, 23, and 27 of the Charter were violated as s. 23 entitled them to have their children educated in French language facilities. Mr. Justice Purvis, in the Court of Queen's Bench, held that the Alberta School Act ${ }^{42}$ conflicted with the Charter to the extent that the Act did not provide for a degree of cultural control and management over the school facility by the Francophone parents. His Lordship did not consider the application of s. 27 despite reaching the same conclusion as in the Ontario Reference. The Mahe decision was upheld by the Alberta Court of Appeal, ${ }^{43}$ again, without reference to s. 27's application.

39. Section 23 of the Charter reads:

23(1) Citizens of Canada

(a) whose first language learned and still understood is that of the English or French linguistic minority population of a province in which they reside, or

(b) who have received their primary school instruction in Canada in English or French and reside in a province where the language in which they received that instruction is the language of the English or French linguistic minority population of the province,

have the right to have their children receive primary and secondary school instruction in that language in that province.

(2) Citizens of Canada of whom any child has received or is receiving primary or secondary school instruction in English or French in Canada, have the right to have all their children receive primary and secondary school instruction in the same language.

(3) The right of citizens of Canada under subsections (1) and (2) to have their children receive primary and secondary school instruction in the language of the English or French linguistic minority population of a province

(a) applies wherever in the province the number of children of citizens who have such a right is sufficient to warrant the provision to them out of public funds of minority language instruction; and

(b) includes, where the number of those children so warrants, the right to have them recieve that instruction in minority language educational facilities provided out of public funds.

40. Supra, n. 37 D.L.R. at 529.

41. (1985) 64 A.R. 35 (Alta. Q.B.).

42. R.S.A. 1980 , c. S-3 and Reg. No. $490 / 82$.

43. Mahe, Martel, Dube, and Association de L'ecole George et Julia Gubnet v. Alberta, Unreported, August 24, 1987. 


\section{CRIMINAL LAW}

In the case of $R$. v. Keegstra, ${ }^{44}$ an application was made by the accused to have s. 281.2(2) of the Criminal Code ${ }^{4 s}$ declared unconstitutional as infringing s. 2(b) (freedom of speech) of the Charter. As the criminal statute prohibits the wilful promotion of hatred against an identifiable group, Justice Quigley combined ss. 15(1) and 27 together with the preamble to the Canadian Bill of Rights, ${ }^{46}$ to support his findings that freedom of speech does not include the commission of the prohibited act under s. 281.2(2). In his judgment, the learned Justice provided an enlightened approach as to how s. 27 coloured the rights and freedoms of the Charter:47

This section compels an interpreter of the Charter to do so in a particular way. Is it in accord with a requirement to interpret the Charter in a manner consistent with the preservation and enhancement of the multicultural heritage of Canadians to interpret the phrase "freedom of expression" as including the freedom to publically and willfully promote hatred against a section of the Canadian public distinguished by colour, race, religion or ethnic origin? In my view, the only rational answer is "No".

In His Lordship's view, the effect of s. 27 was to exclude one type of speech (wilful promotion of hatred toward an identifiable group) from $s$. 2(b) for the purpose of enhancing the freedom of speech of certain sectors of society (presumed here to mean minority and ethnic groups) who might otherwise, through fear of retribution, be inhibited from exercising it.

The Alberta Court of Appeal, however, did not agree with Justice Quigley's interpretation. Mr. Justice Kerans, speaking for a unanimous Court, concluded that the attempt at defining freedom of expression through the vehicle of the ss. 15 and 27 alliance, results in an issue of competing claims within the Charter and, therefore, falls to be determined under S. 1 alone: ${ }^{48}$

Insofar as the Chambers Judge's concern about harmful speech raises ideas about the need to balance free speech against other claims, such as the right of others to protection from harm, that is a section 1 consideration.

44. Unreported, June 6, 1988 Nos. 17699 and 17701 (Alta. C.A.); revg. (1985) 19 C.C.C. (3d) 254 (Alta. Q.B.).

45. R.S.C. 1970 , c. C-34, as am.

46. S.C. 1960, c. 44 . The preamble reads:

The Parliament of Canada affirming that the Canadian Nation is founded upon principles that acknowledge the Supremacy of God, the dignity and worth of the human person and the position of the family in a society of free men and free institutions;

Affirming also that men and institutions remain free only when freedom is founded upon respect for moral and spiritual values and the rule of law:

And being desirous of enshrining these principles and the human rights and fundamental freedoms derived from them in a Bill of Rights which shall reflect the respect of Parliament for its constitutional authority and which shall ensure the protection of these rights and freedoms in Canada;

Therefore Her Majesty, by and with the advice and consent of the Senate and House of Commons of Canada, enacts as follows:

47. Supra, n. 44 C.C.C. at 268.

48. Id. unreported decision at 17. 
Justice Kerans concluded: ${ }^{49}$

... imprudent promotion of hatred falls within the definition of freedom of expression.

Moreover, this legislation fails the proportionality test in section 1 of the Charter.

As a result, the conviction of Mr. Keegstra was overturned, and s. 281.2 of the Criminal Code was rendered of no force and effect by application of $s$. 52 of the Charter.

Curiously, the Court of Appeal read s. 27 in conjunction with s. 15 only, and not with s. 2(b). It is this author's opinion that the Court of Appeal failed to follow the imperative language of s. 27 and apply it constituitively to s. 2(b). The better view is that taken by Justice Quigley whereby s. 2(b) is to be read in light of s. 27 and not in conflict with it. Such an approach would define the types of expression that fall within s. 2(b) even before entering a s. 1 analysis.

In $R$. v. Kent ${ }^{\text {so }}$ one of the accused appealed his first degree murder conviction on the grounds that, inter alia, he was not tried by a jury of his peers. Since he was a native Indian he claimed that the jury should have contained "several" Indians rather than just one. By not having such a jury the appellant claimed an infringement of his Charter rights under ss. 7, 15, 25 and 27. While the appellant used ss. 15(1) and 27 to equate a "jury of peers" to a "jury of equals", that is, the same race, culture, and language of the accused, the Crown asserted the opposite: ss. 15(1) and 27 entitle every qualified citizen to be called for jury duty. The Court agreed with the Crown: ${ }^{\text {s1 }}$

The equality provisions of $s .15$ do not require a jury composed entirely or proportionately of persons belonging to the same race as the accused. An accused has no right to demand that members of his race be included on the jury. To so interpret the Charter would run counter to Canada's multicultural and multiracial heritage and the right of every person to serve as a juror (unless otherwise disqualified). It would mean the imposition of inequality.

The ruling seems reasonable considering the fact that of the one hundred and forty-eight citizens arbitrarily summoned for jury duty, only two were Indian.

An accused's right to be tried within his own community was at issue in the case of $R$. v. Fatt. ${ }^{52}$ In a discussion of s. 27, Mr. Justice Marshall held that due to the section's legitimization of the policy of cultural pluralism: ${ }^{33}$

... it seems that when a relatively homogeneous group, culturally and traditionally, live in a distinct geographic area (indeed as the Dene or the Inuit do) - if the jury is to fulfill its purported role - it will do this only if the jurors reflect the values and cultural mores of that community.

Since the accused lived in an isolated community that had only one hundred potential jurors, a change of venue was considered necessary and an order to try the case in a different northern community was made. This second community was presumed to have the same cultural mores and values as the community in which the accused lived.

49. Id. at 16 .

50. (1986) 40 Man. R. (2d) 160 (Man. C.A.).

51. Id. at 174-175.

52. [1986] N.W.T.R. 388 (S.C.).

53. Id. at 398. 


\section{SOME OBSERVATIONS}

In reviewing the case law above, three general observations are submitted:

\section{A. THE EXTENT OF SECTION 27'S EFFECTIVENESS}

As seen from the decisions in the Supreme Court of Canada and the majority in the Ontario Court of Appeal in Reference Re An Act to Amend the Education Act, ${ }^{\text {s4 }}$ the extent of s. 27 combined with s. 15(1) of the Charter does not go so far as to instill a true concept of equality between religious groups. This case stands for the proposition that rights and privileges guaranteed to denominational schools in s. 93 of the Constitution Act, 1867 shall be considered entrenched, and, therefore, further legislation made in relation to these privileges may be held as constitutionally valid. As well, in Reference Re Education Act of Ontario and Minority Language Education Rights, ${ }^{55}$ s. 27 was used to strengthen the minority language education rights of Francophones in Ontario. The same was done in the Mahe ${ }^{36}$ case. Although these last two cases supported the rights of a minority, the groups had special status under s. 23 of the Charter. The point here is that special rights and privileges conferred on certain groups in Canadian society are still entrenched despite ss. 27 and 15(1). The Constitution clearly favours the Christian religions and the Anglophone and Francophone communities. The extent of s. 27 seems to go only so far as to not affect the privileged relationship that the above named groups have over the "true" minority cultures. Thus, the notion of an Orwellian equality exists: All are equal, but some are more equal than others; or to put it in more recognizable terms - bilingualism, and biculturalism.

\section{B. MAJORITARIAN ETHNOCENTRISM}

Section 27 states, in part, "this Charter shall be interpreted ...", therefore, using imperative language to impose a duty on a court, both its judges and counsel, to address the cultural issues involved in any Charter matter. Unfortunately, one gets a sense from reading some of the recent judgments, that the courts do not really understand the positions and concerns of the minorities, nor do they care to understand. The best evidence of this can be found in portions of the Supreme Court's dicta in $E d w a r d s .{ }^{57}$ In that case, evidence was tendered by respondent counsel showing that the days of religious observance for Moslems and Hindus were not Sundays, but rather Fridays and Wednesdays respectively. Chief Justice Dickson determined that conclusive evidence was lacking and, therefore, dismissed the matter. Why did he not inquire? It is the opinion of this author that the Court should have called for further submissions on the issue so as to make a more informed decision. His Lordship preferred to bolster the argument for upholding the Sunday observance legislation, by creating examples to justify the conclusions made in a report advocating

54. Supra, n. 31 and n. 35.

55. Supra, n. 37.

56. Supra, n. 41.

57. Supra, n. 17. 
[VOL. XXVI, NO. 3

Sunday observance legislation, ${ }^{58}$ written twelve years before the Charter was enacted.

A better example of this ethnocentric attitude is Mr. Justice Beetz's conclusion that it was not the impugned legislation which caused the Jewish, Moslem and Hindu store owners a financial burden, rather it was their religions that did! It is respectfully submitted that this reasoning is patently backward, and that it creates the further harm of obscuring a serious discrimination issue by degrading it to a moot point rivalling the "chicken and the egg" debate. Would a similar conclusion have been made if the statute declared Tuesdays as holidays and Sundays not? Is such a conclusion consistent with the preservation and enhancement of the multicultural heritage of Canadians?

\section{THE ATTITUDE TOWARDS SECTION 27}

Although s. 27 has been used in a number of cases, most courts have shown a reluctance to acknowledge the application of the section. In Edwards - a case having everything to do with multiculturalism - s. 27 was not discussed by six of the seven judges. Even Justice Tarnopolsky, a noted author on the interpretation of s. 27, ignored its relevance in $R e$ an Act to Amend the Education Act. ${ }^{59}$

It is probably the political genesis of the section that hampers its effectiveness. Section 27 was added to the Charter by the Special Joint Committee of the Senate and House of Commons in response to lobby efforts by various ethnic societies in Canada. Although this was not a simple appeasement scheme, the courts may have interpreted it as such. Looking at the relatively few judgments that $\mathrm{s} .27$ has made its appearance in, we can guess that the courts view the provision as more declarative than interpretive. It is more likely that $\mathrm{s} .27$ will be provided more respect in the future when the political background of the section's inclusion will be less at the forefront of the minds of the courts.

A second possible reason for the courts' avoidance of the section is the potential power that it, in combination with ss. 2 and 15 , could have. Basically, the courts might not know how to deal with $\mathrm{s} .27$ yet. What does the section really mean? What are its limits? This second question has been partially answered by the Supreme Court's decision in $\operatorname{Ref} \operatorname{Re} A n$ Act to Amend the Education Act: $:^{60}$ the Charter will not extend to infringing those entrenched privileges granted to certain minorities at the time of Confederation under the Constitution Act, 1867. Hopefully, this decision will bring some guidance to those lower courts that have been reluctant to entertain many of the possibilities the Charter has created for fear of misinterpreting or over-extending its application. This guidance should elicit more application and dicta regarding s. 27 as judges and practitioners alike will realize that the provisions of the Charter will not be wielded against constitutionally entrenched privileges in Canadian society.

58. Supra, n. 23.

59. See Tarnopolsky, W.S. "The Effect of Section 27 on the Interpretation of the Charter" 4:3 Crown Counsel's Review 1.

60. Supra, n. 31 and 35 . 


\section{FUTURE APPLICATION}

As the interpretation of the Charter develops throughout the future, practitioners of law should be cognizant of the various possible applications of s. 27. A method of interpreting s. 27 will have to be incorporated with existing doctrines and tests of constitutionality. Borrowing from the analysis of Justice Quigley in $R$. v. Keegstra, ${ }^{61}$ this author suggests a possible test to be used in future applications of s. 27 .

To place this analysis in perspective, we must first ensure that the established procedure with respect to Charter rights issues is followed; that is, a two step process involving first, an inquiry into whether the Charter right has been infringed, and if so, applying the second step to determine whether the infringement is a reasonable limitation demonstrably justified in a free and democratic society under s. 1 of the Charter ${ }^{62}$

It is suggested here, that coupled with this two step test, should be the interpretive provision of $s$. 27. Therefore, following the two step format, the first question should be: Is it in accordance with a requirement to interpret the Charter in a manner consistent with the preservation and enhancement of the multicultural heritage of Canadians to interpret the section of the Charter which the party claims it has a right or freedom under, as including the act, omission, or claim that that party has committed or has put forth? If the answer is yes, then the second question is: Is it in accordance with a requirement to interpret the Charter in a manner consistent with the preservation and enhancement of the multicultural heritage of Canadians to define the infringement in question as a reasonable limit demonstrably justified in a free and democratic society? If the answer is no, then the party's claim is valid.

The first question would act to screen out all claims that are not guaranteed as rights or freedoms under the particular Charter provision. An example of this is Justice Quigley's conclusion that freedom of expression does not include the freedom to publicly and wilfully promote hatred towards an identifiable group. The second question considers the extent of the party's right or freedom in consideration of the preservation and enhancement of the multicultural heritage of Canadians. Section 27 applied here should provide greater guidance in defining what is reasonable and thereby act to enhance certain rights and freedoms in some cases, and limiting certain rights and freedoms in others.

\section{CONCLUSION}

It has been the main objective of this author to review the case law involving s. 27 of the Charter. A brief review has shown that despite efforts by some judges to incorporate s. 27's interpretive effect, the section, for various reasons, has not had much impact. Where it does have an impact, it is not always certain that the section, in combination with $s .15(1)$, will break down some of the barriers to true cultural pluralism and equality. If there is a change in the perception of $s .27$, from being merely a declaratory provision, to being a true canon of construction, it will have a much greater effect. As the section implies a teaching of cultural tolerance, this can ony enhance the quality of the Charter, and consequently, our society.

61. Supra, n. 44.

62. Supra, n. 24. 